\title{
Climate and crop yields impacted by ENSO episodes on the North China Plain: 1956-2006
}

\author{
Yuan Liu $\cdot$ Xiaoguang Yang $\cdot$ Enli Wang • \\ Changying Xue
}

Received: 12 September 2012/ Accepted: 30 March 2013/Published online: 13 April 2013

(C) The Author(s) 2013. This article is published with open access at Springerlink.com

\begin{abstract}
El Niño-Southern Oscillation (ENSO) contributes to climate anomalies, especially those related to regional rainfall, which affect crop production. Although the North China Plain (NCP) is the most important agricultural production region in China, the impact of ENSO events on local climate and crop production has received only limited attention. Therefore, the impact of different phases of ENSO on local climate and production of winter wheat and summer maize, both rain fed and irrigated, was investigated at three sites using the agricultural production systems simulator model. Data on daily temperature, precipitation, and sunshine hours for 50 years (1956-2006) were analysed to build climate scenarios for three categories of ENSO: years with El Niño events, years with La Niña events, and neutral years. The pattern of climate
\end{abstract}

Y. Liu

Key Laboratory of Agricultural Environment,

Ministry of Agriculture of China, Beijing 100081, China

Y. Liu

Institute of Agricultural Environment and Sustainable

Development, Chinese Academy of Agricultural Sciences,

Beijing 100081, China

Y. Liu $\cdot$ X. Yang $(\bowtie)$

College of Resources and Environmental Sciences, China

Agricultural University, No. 2 Yuanmingyuan West Rd., Haidian

District, Beijing 100193, China

e-mail: yangxg@cau.edu.cn

E. Wang

CSIRO Land and Water, Black Mountain, GPO Box 1666,

Canberra, ACT 2601, Australia

C. Xue

Henan Institute of Meteorological Science, 110\# Jinshui Rd., Jinshui District, Zhengzhou 450003, Henan Province, China change was generally similar across the three sites: annual precipitation decreased slightly and annual mean sunshine hours decreased significantly, whereas annual mean minimum temperature increased significantly, leading to a significant increase in mean air temperature. Precipitation decreased and temperature and sunshine hours increased in both El Niño and La Niña years but remained stable in neutral years. Under full irrigation, the probability of exceeding distribution that crop yield would be higher was not markedly affected $(P>0.05)$, although the yields in both El Niño and La Niña years differed markedly from those in neutral years, especially in maize. Under rain-fed conditions, the yield of maize was decreased greatly $(P<0.05)$, the probability distribution of such reduction being the highest in La Niña years at all the sites $(P<0.05)$. At the provincial level, yields from wellmanaged fields differed $(P>0.05)$ with the ENSO category: production of maize was more vulnerable than that of wheat in El Niño and La Niña years. El Niño and La Niña had similar effects on climatic variables across the NCP: low yields in El Niño and La Niña years due to lower precipitation and high yields in neutral years due to longer sunshine hours and additional irrigation.

Keywords ENSO $\cdot$ El Niño $\cdot$ La Niña $\cdot$ Crop yield . Climate change $\cdot$ North China Plain

\section{Introduction}

El Niño-Southern Oscillation (ENSO), the most widely known source of inter-annual variability in climate (Bjerknes 1969; Loon and Rogers 1981; Ropelewski and Halpert 1986; Lin and Yu 1990, 1993), has a significant impact on global rainfall although the extent of impact 
varies with the region (Waddington 1994; Stone et al. 1996). ENSO refers to the year-to-year variations in sea surface temperatures (SSTs), surface air pressure, convective rainfall, and atmospheric circulation that occur across the equatorial Pacific Ocean (Philander 1990). Many statistical connections have been found between ENSO events and precipitation anomalies around the world (Ropelewski and Halpert 1987; Cane et al. 1994; Yakir et al. 1996), for example, the established ENSO signal, the 'Pacific Decadal Oscillation' (PDO), the 'Atlantic Multi-decadal Oscillation' (AMO), and the 'North Atlantic Oscillation' (NAO), all of which have been shown to influence the variability of stream flow in the USA (Tootle et al. 2005).

It has been shown that not all severe droughts or floods in China were associated with El Niño or La Niña events (Lau and Weng 2001). On average for the country as a whole, approximately 53 and $49 \%$ of the variation in rainfall in 1997 and 1998, respectively, can be attributed to the anomalies in SST associated with El Niño modes (Lau and Weng 2001). Also, Zhang et al. (1999) found that early summer precipitation in Yunnan was related to the variation in SST across equatorial east Pacific and convective activity over the South China Sea. Furthermore, Chinese researchers have shown that anomalies in summer climate can be traced to ENSO events and are particularly important to agriculture in China (Huang and $\mathrm{Wu}$ 1989). In China, temperatures were lower in spring and summer and higher in autumn and winter in El Niño years than in La Niña years (Zhao 1989). Such changes often have a significant impact on crop production.

The impacts of ENSO on crop production have been studied in many countries (Handler 1990; Cane et al. 1994; Carlson et al. 1996; Meinke et al. 1998). In general, yields in La Niña years have been higher in countries west of the Pacific and lower in those east of the Pacific. Simulations were also conducted to investigate the influence of ENSO phases on yields of peanut in Australia (Meinke and Hammer 1995), maize in Zimbabwe (Phillips et al. 1998), and several crops in other countries (Hansen et al. 1998; Messina et al. 1999). In China, only one study significantly linked rice production in northern and north-western China with ENSO (Zhang et al. 2008). The monthly Southern Oscillation Index (SOI) is widely used as a measure of the strength of ENSO (Gordon 1986; Ropelewski and Halpert 1987) and was also used for measuring the correlation between the SOI and rainfall in Australia (Mcbride and Nicholls 1983). Although the North China Plain (NCP) is agriculturally the most important region in China, the impact of ENSO on climate and crop production in the region has received only limited attention. Because ENSO is the largest signal in the inter-annual variation in the atmosphere-ocean system and affects global climate, the related climatic variability and crop production along with ENSO are among the most important frontiers of research in China. Therefore, the present study sought to: (1) describe the trends in a few climatic variables and analyse the impact of ENSO on them in the NCP and (2) study the effect of three phases of ENSO (years with El Nino events, years with La Nina events, and neutral years) on yields of winter wheat and summer maize.

\section{Materials and methods}

\section{Study sites}

Three study sites (Fig. 1) were selected from the observational stations of the National Meteorological Network of Central China Meteorological Administration (CMA), namely Nanyang $\left(33.0^{\circ} \mathrm{N}, 112.6^{\circ} \mathrm{E} ; 129.2 \mathrm{~m}\right)$ and Zhengzhou
Fig. 1 Location of agricultural experimental stations across the NCP: Nanyang and Zhengzhou in Henan province and Luancheng in Hebei province

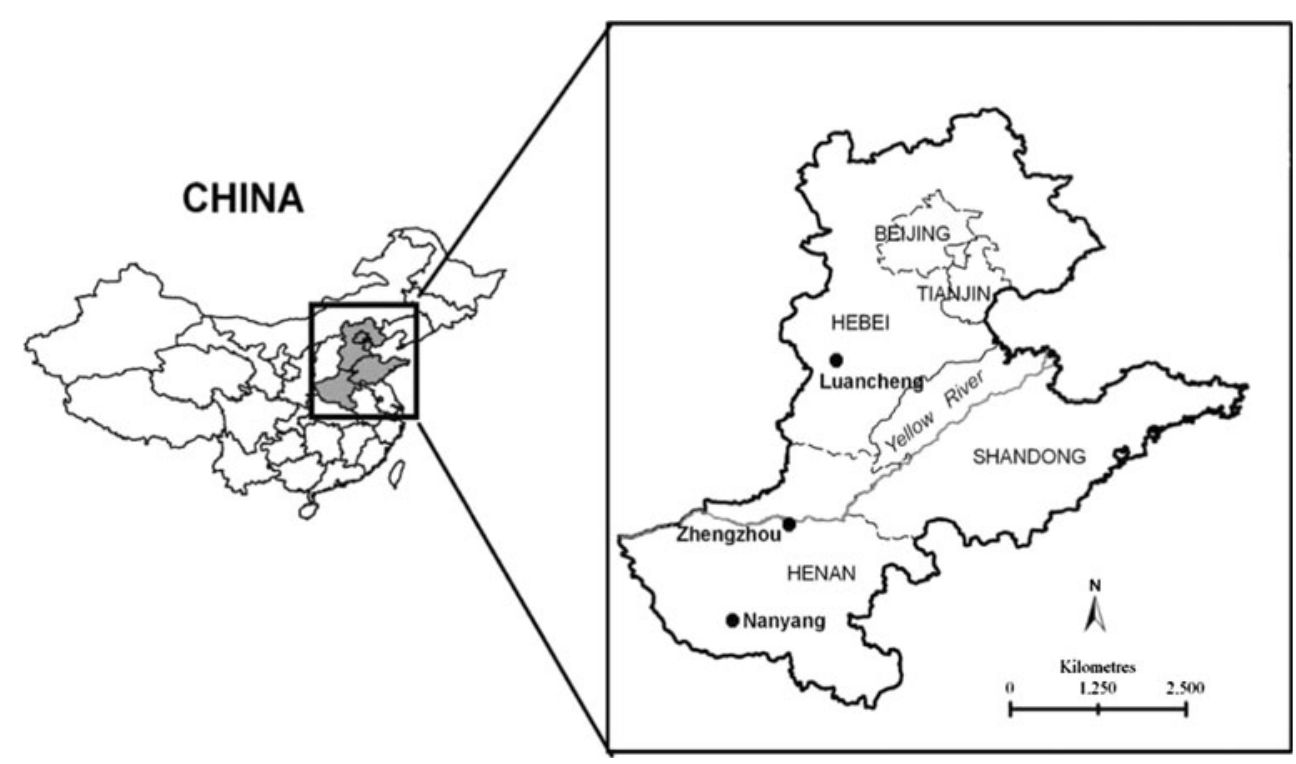


Table 1 Basic experimental information on the crop (typical average dates of sowing, anthesis, and maturity) and the weather (annual mean temperature, annual mean sunshine hours, and annual total precipitation) from 1981 to 2005 at the study sites

\begin{tabular}{|c|c|c|c|c|c|c|}
\hline \multirow{2}{*}{$\begin{array}{l}\text { Event or } \\
\text { variable }\end{array}$} & \multicolumn{2}{|c|}{ Nanyang } & \multicolumn{2}{|c|}{ Zhengzhou } & \multicolumn{2}{|c|}{ Luancheng } \\
\hline & Wheat & Maize & Wheat & Maize & Wheat & Maize \\
\hline $\begin{array}{l}\text { Planting date } \\
\text { (day/month) }\end{array}$ & $23 / 10$ & 08/06 & $15 / 10$ & 07/06 & $04 / 10$ & $05 / 06$ \\
\hline $\begin{array}{l}\text { Flowering date } \\
\text { (day/month) }\end{array}$ & $06 / 05$ & 03/08 & $26 / 04$ & 01/08 & $26 / 04$ & $31 / 07$ \\
\hline $\begin{array}{r}\text { Maturity date } \\
\text { (day/month) }\end{array}$ & $29 / 05$ & $14 / 09$ & $31 / 05$ & $11 / 09$ & 08/06 & $16 / 09$ \\
\hline $\begin{array}{l}\text { Mean } \\
\text { temperature } \\
\left({ }^{\circ} \mathrm{C}\right)\end{array}$ & 13.8 & 25.6 & 13.9 & 25.0 & 14.5 & 25.5 \\
\hline $\begin{array}{l}\text { Mean sunshine } \\
\text { hours }(\mathrm{h})\end{array}$ & 5.1 & 5.8 & 6.1 & 6.0 & 6.9 & 6.4 \\
\hline $\begin{array}{l}\text { Precipitation } \\
\quad(\mathrm{mm})\end{array}$ & 229 & 440 & 199 & 360 & 142 & 367 \\
\hline
\end{tabular}

$\left(34.8^{\circ} \mathrm{N}, 113.7^{\circ} \mathrm{E} ; 80.0 \mathrm{~m}\right)$ in Henan province and Luancheng $\left(37.9^{\circ} \mathrm{N}, 114.6^{\circ} \mathrm{E} ; 52.5 \mathrm{~m}\right)$ in Hebei province. These sites were chosen because long-term crop data were available for each and because they were located along the south-north axis of the NCP. Both annual air temperature and annual rainfall decrease from the south to the north. For Nanyang, Zhengzhou, and Luancheng, the mean values of annual mean air temperature are $15.0,14.4$, and $13.4{ }^{\circ} \mathrm{C}$ and of annual precipitation are 784, 643, and $528 \mathrm{~mm}$, respectively (Table 1).

Weather and crop data

Daily weather data from 1956 to 2006 on precipitation, sunshine hours, and maximum, average, and minimum temperature were available from CMA. Data on yields of winter wheat and summer maize at the provincial level for 50 years (1956-2006) were collected from the China Agriculture Yearbook (China Statistics Press 2007). A wheat-maize double rotation was practised from 1981 to 2005 at each of the agro-meteorological experimental stations. Typical sowing, flowering, and harvest dates for the crops are shown in Table 1.

\section{ENSO phases/years}

Detailed categorization of ENSO is shown in Table 2, which is based on an index from the Japan Meteorological Agency. The index is a 5-month running mean of spatially averaged anomalies in SST over the tropical Pacific: $4^{\circ} \mathrm{S}$ to $4^{\circ} \mathrm{N}$ and $90^{\circ} \mathrm{W}$ to $150^{\circ} \mathrm{W}$. When the index values were greater than $0.5^{\circ} \mathrm{C}$ in a given ENSO year for six consecutive months from October, the year was categorized as an
Table 2 Categorization of ENSO years (1956-2006) based on the Japan Meteorological Agency's tropical Pacific sea surface temperature anomaly (SSTA) index

\begin{tabular}{llll}
\hline $\begin{array}{l}\text { El Niño years } \\
\text { (warm event) }\end{array}$ & Neutral years & $\begin{array}{l}\text { La Niña years } \\
\text { (cold event) }\end{array}$ \\
\hline 1957 & 1958 & 1984 & 1956 \\
1963 & 1959 & 1985 & 1964 \\
1965 & 1960 & 1989 & 1967 \\
1969 & 1961 & 1990 & 1970 \\
1972 & 1962 & 1992 & 1971 \\
1976 & 1966 & 1993 & 1973 \\
1982 & 1968 & 1994 & 1975 \\
1986 & 1974 & 1995 & 1988 \\
1987 & 1977 & 1996 & 1998 \\
1991 & 1978 & 2000 & 1999 \\
1997 & 1979 & 2001 & \\
2002 & 1980 & 2003 & \\
2006 & 1981 & 2004 & \\
& 1983 & 2005 & \\
\hline
\end{tabular}

El Niño year; when lower than $-0.5^{\circ} \mathrm{C}$, the year was categorized as a La Niña year (Sittel 1994a). Of the 51 years of the study period, 13 were El Niño years, 10 were La Niña, and 28 were neutral (Table 2).

Data analysis and preparation

For a more reliable comparison of the different climatic indicators, namely temperature, precipitation, and sunshine
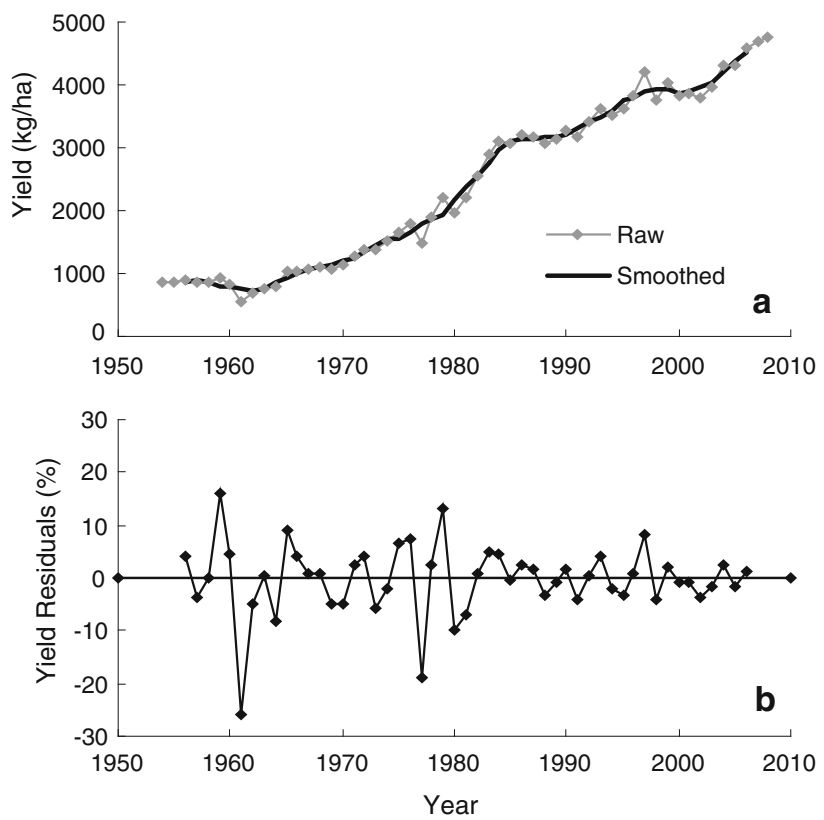

Fig. 2 Raw (grey dots 1956-2006) and smoothed (black line 1958-2004) time series (a) and the detrended residuals (1958-2004) (b) of wheat yield across the whole of China 
hours, the trends were removed by detrending the time and leaving the year-to-year residuals, as shown in the following equation.

$Y=\frac{x-\bar{x}}{\bar{x}} \times 100 \%$

where $Y$ is the residuals (\%), $x$ is the actual value, and $\bar{x}$ represents the smoothed 5-year running means. Trend analysis of the climatic variables during the three phases or categories of ENSO was carried out by examining the slope of the linear regression line of the target variable against time using Student's $t$ test at a confidence level above 95 or $99 \%$. The contrasting cumulative probability distributions of the climatic variables and of crop yield indicators under the three ENSO phases and for the total period were tested by the Kolmogorov-Smirnov (KS) test.

Smoothed time series of observed national yields (for wheat) were calculated with a 5-year running mean (Fig. 2a). Inter-annual residuals were calculated by subtracting the raw and smoothed time series. It was assumed that these detrended results are free of non-climate-related influences such as improved varieties, better management, more irrigation, and higher doses of fertilizers since 1956 (Fig. 2b). This assumption made it possible to examine inter-annual yield residuals, which are generally considered sensitive to weather variations. Similar transformations were commonly performed at other research stations. The growth period of wheat was divided into two stages: stage 1 (October-February), which spans the autumn and the winter and stage 2 (MarchMay), which is confined mainly to the spring. Maize season is from June to September and is confined mainly to the summer.

\section{Crop simulations}

Agricultural production systems simulator (APSIM) is a farming systems model that can simulate crop rotations
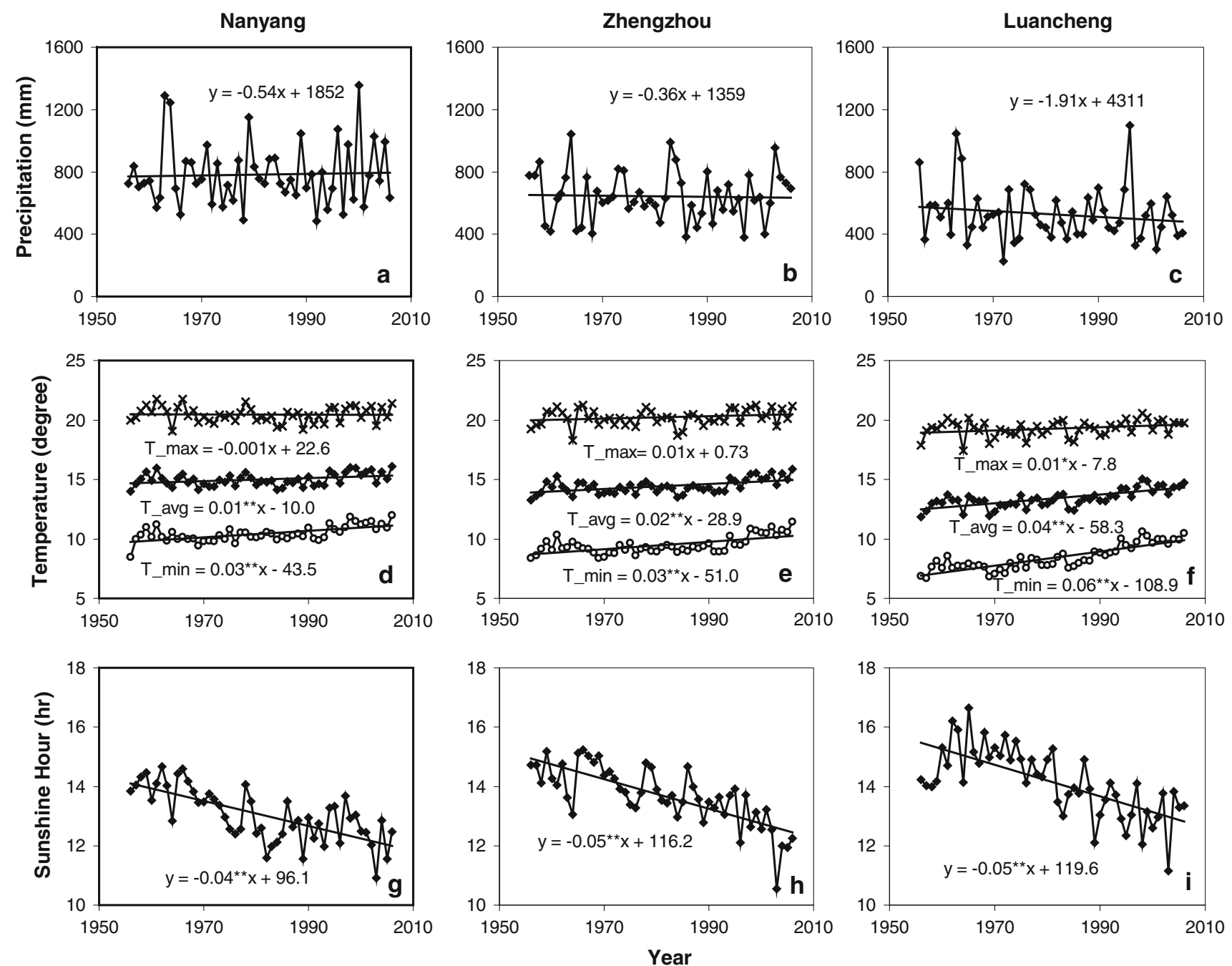

Fig. 3 Trends in annual precipitation $(\mathbf{a}-\mathbf{c})$, annual mean temperature $(\mathbf{d}-\mathbf{f})$, and annual mean sunshine hours $(\mathbf{g}-\mathbf{i})$ from 1956 to 2006 at the three sites. The straight line is the linear regression line against year. **Significant at $P<0.01$; *significant at $P<0.05$ 
Table 3 Trends in standardized climatic parameters at different growth stages according to the three ENSO phases

\begin{tabular}{|c|c|c|c|c|c|}
\hline Crop and stage & Item & Phases & Nanyang trend & Zhengzhou trend & Luancheng trend \\
\hline \multirow[t]{18}{*}{ Stage 1 Winter wheat } & \multirow[t]{3}{*}{ Rainfall } & El Niño & -5 & -11 & 38 \\
\hline & & Neutral & 9 & 4 & -3 \\
\hline & & La Niña & -61 & -47 & -53 \\
\hline & \multirow[t]{3}{*}{ Sunshine hours } & El Niño & 1.2 & -0.9 & 3.3 \\
\hline & & Neutral & -1.1 & -0.7 & -0.8 \\
\hline & & La Niña & 10.1 & 5.6 & 11.2 \\
\hline & \multirow[t]{3}{*}{$T_{\text {avg }}$} & El Niño & 5.7 & 1.7 & 3.1 \\
\hline & & Neutral & -2.9 & -3.1 & -5.3 \\
\hline & & La Niña & $25.7^{*}$ & $37.9^{* *}$ & $67.2 * *$ \\
\hline & \multirow[t]{3}{*}{$T_{\max }$} & El Niño & 3.8 & 2.3 & -1.4 \\
\hline & & Neutral & -2.2 & -2.5 & -2.2 \\
\hline & & La Niña & 20.5 & $28.7^{*}$ & $35.9 * *$ \\
\hline & \multirow[t]{3}{*}{$T_{\min }$} & El Niño & -0.1 & -107.8 & 13.8 \\
\hline & & Neutral & -7.0 & 0.8 & 7.6 \\
\hline & & La Niña & 92.1 & 479.7 & $150.1^{* *}$ \\
\hline & \multirow[t]{3}{*}{$T_{\text {diff }}$} & El Niño & 2.1 & 1.7 & -3.0 \\
\hline & & Neutral & -1.4 & -1.8 & -0.7 \\
\hline & & La Niña & 14.8 & 19.7 & 18.1 \\
\hline \multirow[t]{18}{*}{ Stage 2 Winter wheat } & \multirow[t]{3}{*}{ Rainfall } & El Niño & 33 & 22 & 4 \\
\hline & & Neutral & -10 & -10 & 1 \\
\hline & & La Niña & 24 & -16 & -28 \\
\hline & \multirow[t]{3}{*}{ Sunshine hours } & El Niño & -4.6 & -1.6 & 4.3 \\
\hline & & Neutral & 0.6 & -0.3 & --1.1 \\
\hline & & La Niña & -2.3 & -11.5 & -2.1 \\
\hline & \multirow[t]{3}{*}{$T_{\text {avg }}$} & El Niño & 1.2 & 3.4 & 3.4 \\
\hline & & Neutral & -0.7 & -0.8 & -0.7 \\
\hline & & La Niña & -0.2 & -0.6 & 1.9 \\
\hline & \multirow[t]{3}{*}{$T_{\max }$} & El Niño & 0.1 & 1.5 & 1.4 \\
\hline & & Neutral & -0.6 & -0.7 & -0.8 \\
\hline & & La Niña & 0 & -1.6 & 4.1 \\
\hline & \multirow[t]{3}{*}{$T_{\min }$} & El Niño & 1.5 & 6.6 & 7.5 \\
\hline & & Neutral & -0.9 & -0.9 & -0.2 \\
\hline & & La Niña & 0.8 & -4.1 & -7.5 \\
\hline & \multirow[t]{3}{*}{$T_{\text {diff }}$} & El Niño & -1.8 & -2.8 & -2.6 \\
\hline & & Neutral & -0.1 & -0.5 & -1.2 \\
\hline & & La Niña & -2.1 & 4.8 & 10.7 \\
\hline \multirow[t]{18}{*}{ Summer maize } & \multirow[t]{3}{*}{ Rainfall } & El Niño & -40 & -33 & -18 \\
\hline & & Neutral & 14 & 9 & 14 \\
\hline & & La Niña & -40 & -22 & -57 \\
\hline & \multirow[t]{3}{*}{ Sunshine hours } & El Niño & 5.9 & 8.3 & 7.4 \\
\hline & & Neutral & -1.8 & -2.4 & -1.7 \\
\hline & & La Niña & 5.7 & 3.1 & 5.8 \\
\hline & \multirow{3}{*}{$T_{\text {avg }}$} & El Niño & $2.2^{*}$ & $3.2^{*}$ & 1.9 \\
\hline & & Neutral & -0.9 & -0.9 & -0.9 \\
\hline & & La Niña & $3.8^{*}$ & 2.2 & 4.0 \\
\hline & \multirow[t]{3}{*}{$T_{\max }$} & El Niño & $2.9^{*}$ & $3.9^{*}$ & 1.1 \\
\hline & & Neutral & -1.3 & -1.1 & -1.0 \\
\hline & & La Niña & $4.1 *$ & 2.1 & 4.8 \\
\hline & $T_{\min }$ & El Niño & 0.4 & 2.4 & 3.1 \\
\hline & & Neutral & -0.5 & -0.4 & -0.8 \\
\hline & & La Niña & 3.0 & -0.2 & 2.3 \\
\hline & $T_{\text {diff }}$ & El Niño & 9.3 & 7.4 & -2.0 \\
\hline & & Neutral & -3.0 & -2.3 & -1.5 \\
\hline & & La Niña & 0 & 6.0 & 8.7 \\
\hline
\end{tabular}

All units of climatic parameters are percentages of changes per decade due to be standardized. Stage 1 and Stage 2 of winter wheat represent the period from October to February and from March to May, respectively, and the summer maize season is from June to September

$P$ precipitation, $S H$ sunshine hours, $T_{\max }$ maximum temperatures, $T_{\text {avg }}$ average temperatures, $T_{\min }$ minimum temperatures, $T_{\text {diff }}$ diurnal

** Significant at $P<0.01$; * significant at $P<0.05$ 
and effects of management practices worldwide (McCown et al. 1996; Asseng et al. 1998, 2000; Southworth et al. 2000; Keating et al. 2003). APSIM is preferably run with a time resolution of 1 day. The model can simulate, in terms of yield, the response to alternative management practices such as irrigation, fertilizer application, and the choice of cultivar over many years of weather data (Meinke and Hammer 1995; Boote et al. 1996; Mavromatis et al. 2002).

Agricultural production systems simulator has been widely tested in many countries including Australia, the Netherlands, Philippines, and the USA, and also in West Asia and North Africa, under a wide range of conditions on both temporal and spatial scales (Asseng et al. 1998, 2000; Nelson et al. 1998; Lyon et al. 2003; Wang et al. 2003). The model has also been calibrated, validated, and used in China. Sun and Feng (2005) assessed the effects of drought on wheat production using APSIMWheat in Beijing, China. Wang et al. (2007) evaluated APSIM by simulating the production and water use in a wheat-maize double cropping system in the NCP and found that the model predicted crop growth and yield in the study areas reasonably well. Chen et al. (2010a, b), who calibrated and validated APSIM using 3 years of experimental data in Luancheng, also concluded that the model was able to simulate crop yields and water use in wheat-maize rotations in the NCP. In general, these applications of APSIM indicate that simulation can explain at least $60 \%$ of the variation in biomass, yield, and water use in these tested areas. In this study, we relied on the model performance based on the earlier work on model validation and also used the model for constructing vulnerability scenarios of current agricultural management practices in China. The wheat-maize rotation was simulated from 1956 to 2006 using the daily weather data. One cultivar of wheat for each location (Zhengyin_1 for Nanyang, Zhengzhou_761 for Zhengzhou, and Pin_39 for Luancheng) and one of maize (Yunong_704 for Nanyang, Zhengdan_2 for Zhengzhou, and Luyuandan_9 for Luancheng) were used for the entire 50-year period to eliminate the impact of varietal changes. All the cultivars of wheat and maize actually grown in 1981 - the midpoint of the simulation period-were calibrated and validated using

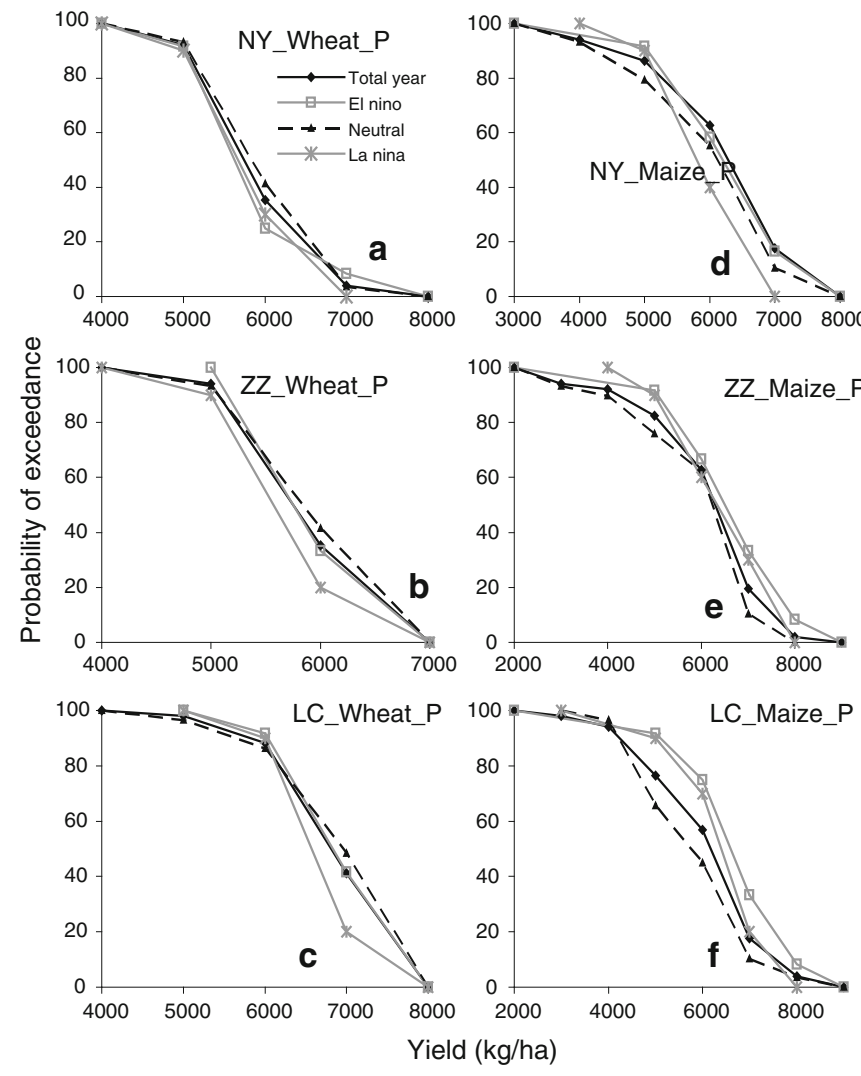

Fig. 4 Cumulative probability distributions of subsequent simulated potential $(\mathbf{a}-\mathbf{f})$ and rain-fed yields $(\mathbf{g}-\mathbf{l})$ of wheat and maize under ENSO phases at Nanyang, Zhengzhou, and Luancheng. Solid black
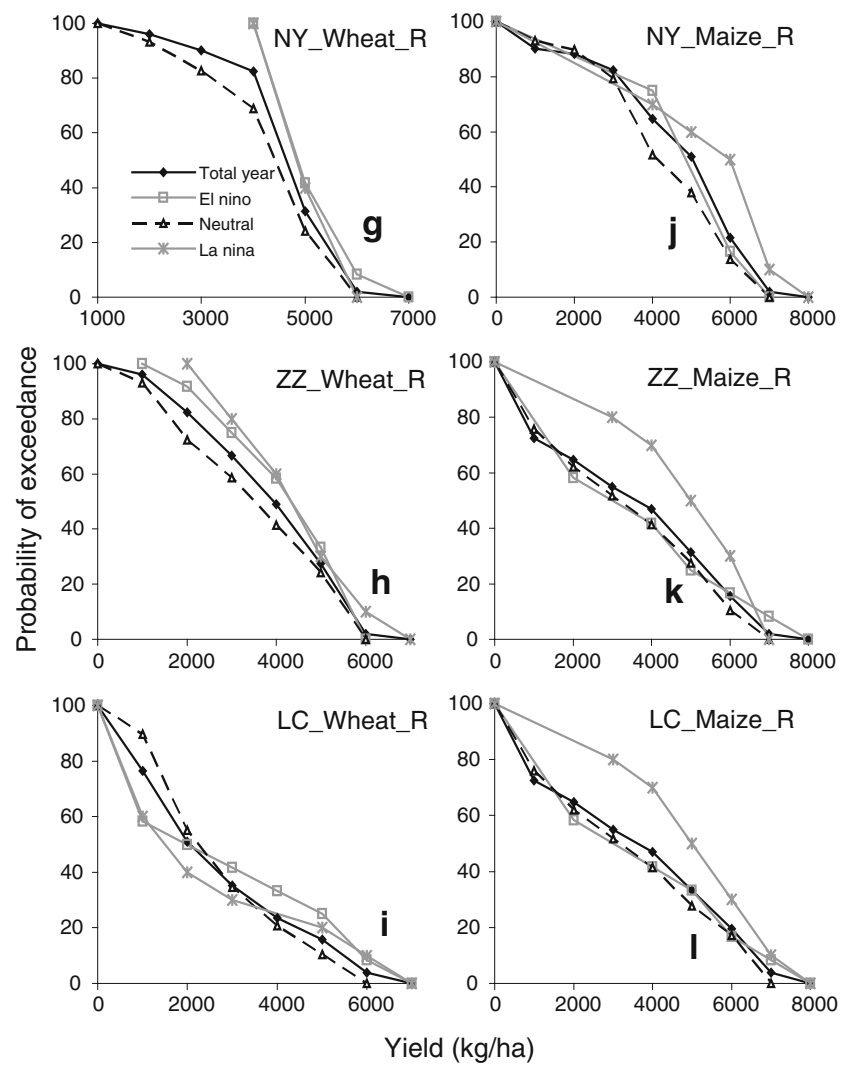

lines show the all-year distribution, Dashed lines show the neutral years, and grey lines with "open square" and "asterisk" show the La Niña and El Niño years, respectively 
Fig. 5 Cumulative probability distributions of subsequent yields of wheat and maize under ENSO phases at the national level and at the provincial level. Dashed lines show the neutral years and grey lines with "open square" and "asterisk" show the La Niña and El Niño years, respectively
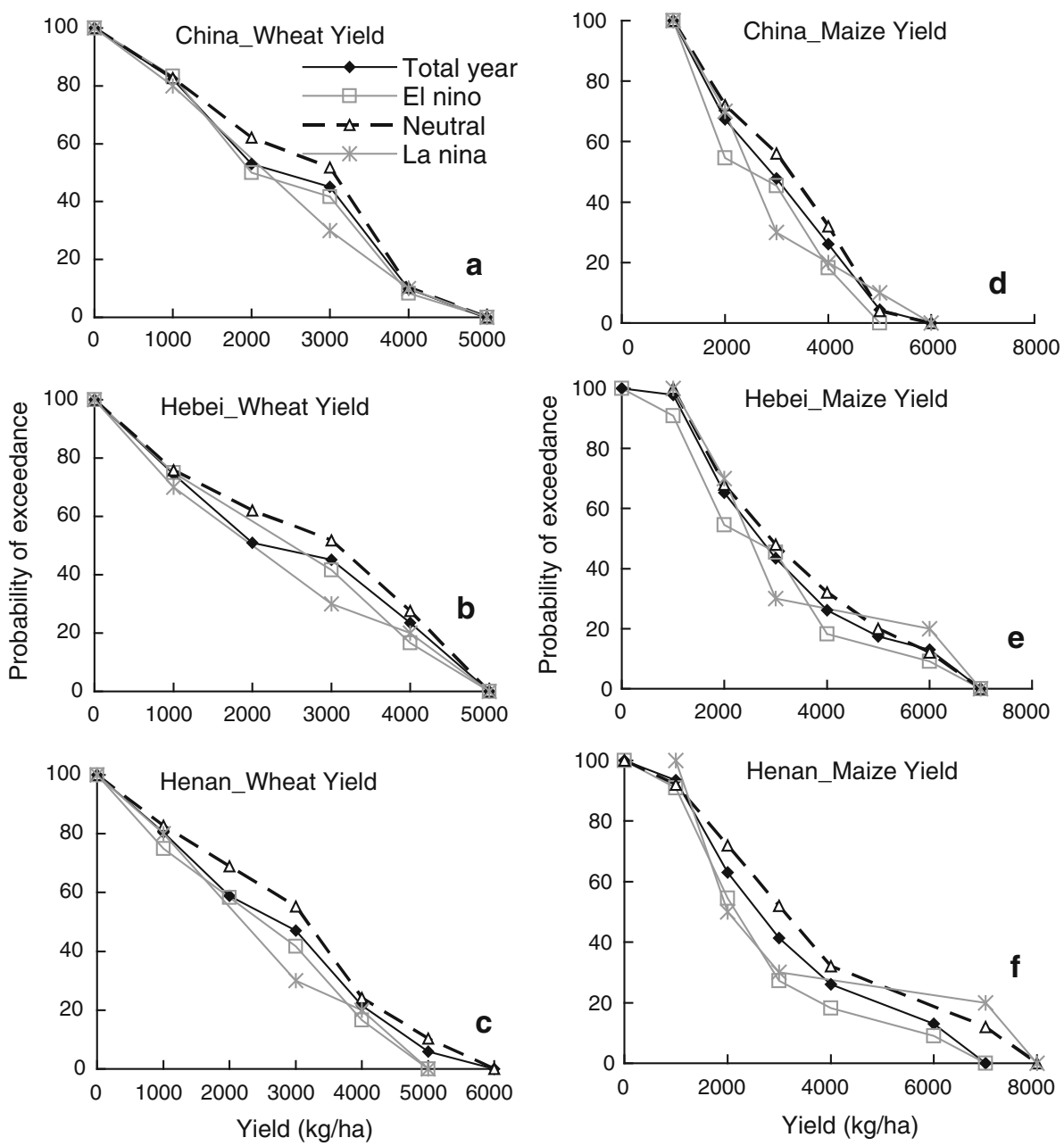

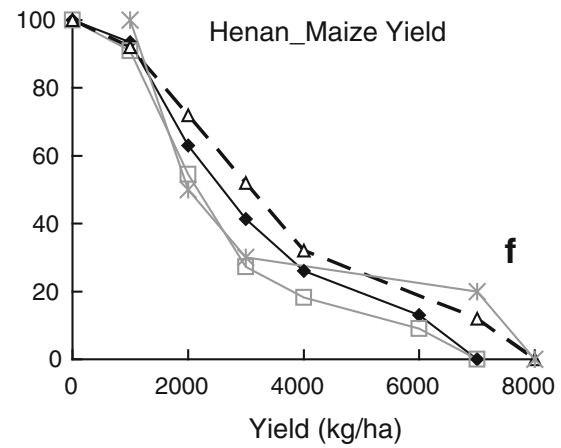

experimental data for each site. All simulations were conducted assuming a full dose of fertilizers to eliminate the impact of nutrient stress. Two water regimes were assumed for each site, namely full irrigation and no irrigation (rain-fed cultivation). The local mean sowing date for each site and crop (Table 1), planting density, and other management practices were kept constant throughout.

\section{Results}

Variability of climatic parameters in ENSO phases

Climate change in China in the twentieth century mainly involved changes in precipitation, sunshine hours, and temperature (Fig. 3). The pattern of changes was generally similar for all the three sites.

Annual precipitation decreased slightly $(P>0.05)$ (Fig. 3a-c), from $-19 \mathrm{~mm}$ per decade at Luancheng to $-4 \mathrm{~mm}$ per decade at Zhengzhou, whereas annual mean sunshine hours decreased significantly by about $0.5 \mathrm{~h}$ per decade $(P<0.01)$ at all the sites (Fig. $3 \mathrm{~g}-\mathrm{i})$. The extent of warming increased from south to north (Nanyang to Luancheng), as seen in the increase in mean temperatures. The annual mean minimum temperature also increased $(P<0.01)$ at each site whereas the annual mean maximum temperature increased only slightly $(P>0.05)$, leading to a significant increase in mean air temperature (Fig. 3d-f), from $0.1{ }^{\circ} \mathrm{C}$ per decade at Nanyang to $0.4{ }^{\circ} \mathrm{C}$ per decade at Luancheng $(P<0.01)$.

Table 3 shows the trends in standardized climatic variables in each ENSO phase. For wheat, residuals of precipitation tended to decline in both El Niño and La Niña years during pre-flowering compared to those in neutral years at Nanyang and Zhengzhou but not at Luancheng, although in none of the cases was the change significant at $95 \%$ CI. Residuals of precipitation during the post-flowering stage tended to increase markedly during both El Niño and La Niña years and to decrease during neutral years for all sites $(P>0.05)$. Likewise, for all the three sites, the number of sunshine hours increased slightly during both El Niño and La Niña years and decreased during neutral years $(P>0.05)$ in stage 1 of wheat 


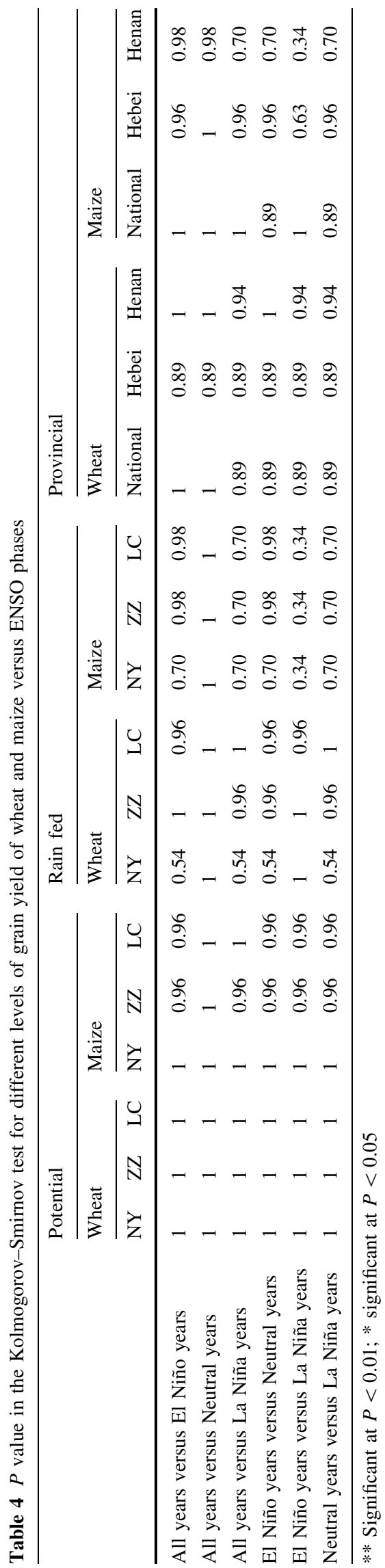

production; in stage 2 , the pattern was the exact opposite $(P>0.05)$. The mean maximum temperature increased during the vegetative stage (stage 1$)$, significantly so at Zhengzhou $(P<0.05)$ and Luancheng $(P<0.01)$, which led to a significant increase in the mean temperature at all sites $(P<0.01)$. During the reproductive stage (stage 2 , from March to May), there was little variation in temperature at any of the sites $(P>0.05)$.

In the case of maize (June-September), residuals of precipitation declined in both El Niño and La Niña years and increased slightly in neutral years at all sites, but none reached the confidence level of $95 \%$. The number of sunshine hours in both the categories was higher than that in neutral years $(P>0.05)$; temperature followed the same pattern, most significantly the mean and maximum temperature in El Niño years at Nanyang $(P<0.05)$ and Zhengzhou $(P<0.05)$ and the maximum temperature in La Niña years at Nanyang $(P<0.05)$.

Variability in crop yields in ENSO phases

Crop yields in the NCP were affected by the phases of ENSO, and the magnitude of the effect varied with the phase. Figure 4 shows the cumulative probability distributions of grain yields of wheat and maize-assuming either full irrigation or no irrigation (rain-fed cultivation) under the three ENSO phases and for total years at all the three sites. Probability distributions of wheat yield assuming full irrigation (Fig. 4a-c) did not differ markedly among the three ENSO phases or for total years, being only slightly lower in La Niña years at Zhengzhou and Luancheng, although none of the differences was significant at the $95 \%$ level (Table 4). In the case of maize (Fig. 4d-f), the distributions were different, although not markedly so, for each of the phases, those for both El Niño and La Niña years being slightly higher than those for neutral years and for total years at every site $(P>0.05)$. In other words, different phases of ENSO affect precipitation and even yields to different degrees. However, irrigation can compensate for the loss in yield due to lower precipitation, resulting in only slight differences in the probability that yields would be affected by the ENSO phases.

Cumulative probability distributions of yields of rain-fed wheat and maize under the ENSO phases are shown in Fig. 4g-1. For wheat (Fig. 4g-i), the probability distributions in El Niño and La Niña years were higher than those for total years at each site, although at Nanyang the differences between El Niño and La Niña events were significant only at the $5 \%$ level. For maize (Fig. $4 \mathrm{j}-1$ ) at all the sites, the lowest probability distributions were seen in El Niño years and reached the confidence level of $95 \%$ in La Niña years.

Probability distributions of wheat and maize yields at the national and provincial levels are shown in Fig. 5. The 

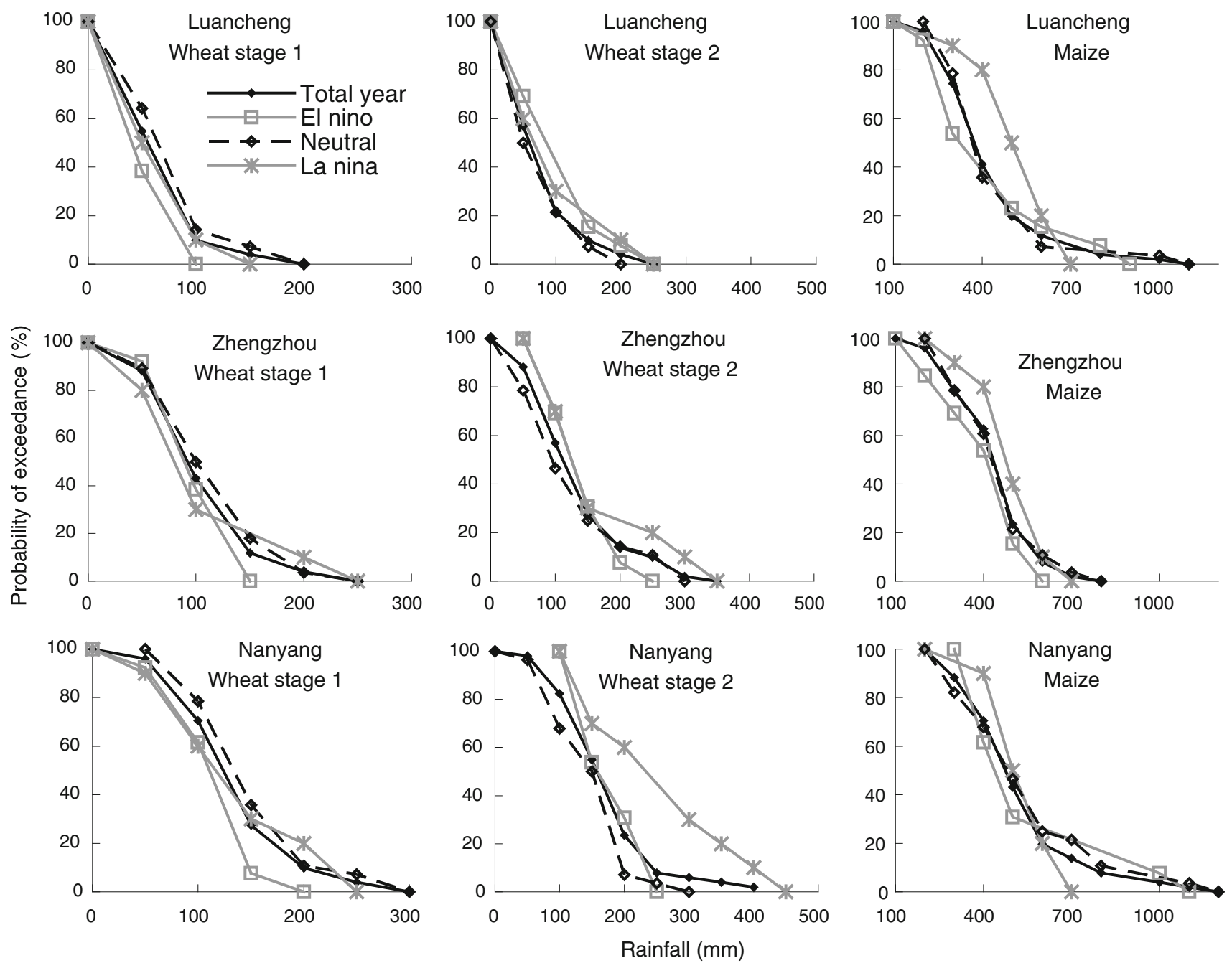

Fig. 6 Cumulative probability distributions of subsequent precipitation at different growth stages of wheat and maize under ENSO phases. Solid black lines show the all-year distribution. Dashed lines show the neutral years, and grey lines with "open square" and "asterisk" show the La Niña and El Niño years, respectively. The

differences were not significant in Hebei and Henan provinces under any of the four periods and were the lowest in La Niña years $(P>0.05)$. Crop yields on a national or provincial scale, especially in Hebei and Henan provinces, two of the principal production areas, showed little change under the ENSO phases $(P>0.05)$ because other factors compensated for the adverse effects.

\section{Discussion}

El Niño and La Niña represent the opposite extremes of the ENSO cycle (Ropelewski and Halpert 1986). However, under these extremes as well as under neutral conditions, the values of SOI are near zero, the long-term average. Studies have shown that La Niña summers tend to be slightly wetter than growth period of wheat was divided into two stages: stage 1 (October-February) spanned the autumn and the winter and stage 2 (March-May) is confined mainly to the spring. The maize season is from June to September, and is confined mainly to the summer

normal in the USA (Sittel 1994a, b). ENSO can also affect climate variability, which has been identified as a key driver of agricultural productivity, especially since it affects the extent to which water is available for agricultural production in the NCP (Waddington 1994; Tao et al. 2003). Huang and $\mathrm{Wu}(1989)$ discovered that weak convective activity around the South China Sea during the developing stage of ENSO may result in drought in the Indo-China peninsula. Liu and Ding (1995) analysed seasonal precipitation and temperature in China during ENSO events for the last 40 years and found that both were lower than normal on the whole in ENSO years, whereas the anomalies were almost exactly the opposite-higher than average rainfall and temperatures-in the following year in most parts of China.

Climate variability was identified as a major constraint to agricultural productivity (Waddington 1994), and 
variability in the availability of water for agriculture in the NCP especially so (Tao et al. 2003). Figure 6 shows the probability of exceeding distributions of higher precipitation in the year following the ENSO phases and in all years, respectively, during the two growth stages of winter wheat, namely stage 1 (pre-flowering) and stage 2 (post-flowering). For stage 1, the probability of higher precipitation differed little among the three ENSO phases and over the total years $(P>0.05)$ at the three sites, although it was a little lower in El Niño and La Niña years than in neutral years and over the total years. For stage 2 of wheat, the probability distribution in La Niña years was significantly higher than that in the other two phases and over the total years $(P<0.05)$ at Nanyang, but differed little $(P>0.05)$ at other sites. The probability of exceedance was the highest in La Niña years and the lowest in El Niño years at the three sites (significantly so at Nanyang and Luancheng; $P<0.05$ ), especially for maize, whereas it was intermediate in neutral years and for total years.

Variations in other climatic variables under the three ENSO phases during different stages of crop growth are not discussed here because the variations were not significantly different. Precipitation, which is the key factor influencing crop yield in the NCP, varies between about 470 and $900 \mathrm{~mm}$ because of the influence of the monsoon, which is active mainly from June to September (Jin et al. 1999), and is thus critical to the productivity of winter wheat-summer maize rotation system. Crops during the summer monsoon (June-September), especially maize in the present context, are subjected to seasonal variability in rainfall associated with ENSO. Wheat growth and grain yields are typically sensitive to variability in precipitation in the spring (Bai et al. 1999), but the seasonal variability associated with ENSO did not affect wheat yield significantly (Fig. 5a-c). Although ENSO's influence on rainfall is spatially less consistent, the growing season tends to be wet in El Niño years and dry in La Niña years. Temperature and the distribution of rainfall during the growing season influence plant growth. Maize needs moisture during the flowering phase for the pollen to stick to the tassels and, later, for filling the grains (Cane et al. 1994).

Evidence has been growing that ENSO influences crop production through its influence on weather patterns in some regions. El Niño events were associated with low grain yields in south Asia and Australia and with high grain yields in the North American prairies (Garnett and Khandekar 1992; Hansen et al. 1998). We tested two extreme cases in this study, namely plentiful water (through irrigation) and scarcity of water (precipitation as the sole source of water), to assess the extent to which lower yields due to the variability of weather can be attributed to limited availability of water (Fig. 4a-1).
Hansen et al. (1998) attributed the effect of ENSO on maize yield in La Niña years primarily to enhanced precipitation in June, a period that coincides with tasselling, the stage at which maize is most susceptible to water stress in southern Georgia. Correlations between ENSO and crop yields in China have been recognized, but research that focuses on causes continues to be inadequate.

Acknowledgments This work was supported by the Ministry of Science and Technology of China ('973' project, Grant No. 2010CB951502), National Key Technology R\&D Program (NO. 2012BAD20B04), the Department of Agriculture (No. 200903003), Basic Scientific Research Foundation of National non-Profit Scientific Institute of China (No. BSRF201102) and also by the CSIRO-Chinese Ministry of Education (MOE) PhD Research Fellowship Program.

Open Access This article is distributed under the terms of the Creative Commons Attribution License which permits any use, distribution, and reproduction in any medium, provided the original author(s) and the source are credited.

\section{References}

Asseng S, Keating BA, Fillery IRP (1998) Performance of the APSIM-wheat model in Western Australia. Field Crop Res 57:163-179

Asseng S, van Keulen H, Stol W (2000) Performance and application of the APSIM-Nwheat model in the Netherlands. Eur J Agron $12: 37-54$

Bai Y, Li S, Huo Z (1999) Identification of the distribution of main agro meteorological disasters in China. In: Li S (ed) Risk assessment and strategies of agricultural disasters in China. Meteorological Press, Beijing, pp 59-71

Bjerknes J (1969) Atmosphere teleconnections from equatorial Pacific. Mon Weather Rev 97:163-172

Boote KJ, Jones JW, Pickering NB (1996) Potential uses and limitations of crop models. Agron J 88:704-716

Cane MA, Eshel G, Buckland RW (1994) Forecasting Zimbabwean maize yield using eastern equatorial Pacific sea surface temperature. Nature 370:204-205

Carlson RE, Todey DP, Taylor SE (1996) Midwestern corn yield and weather in relation to extremes of the southern oscillation. J Prod Agric 9:347-352

Chen C, Wang EL, Yu Q (2010a) Modeling the effects of climate variability and water management on crop water productivity and water balance in the North China Plain. Agr Water Manage 97:1175-1184

Chen C, Wang EL, Yu Q (2010b) Quantifying the effects of climate trends in the past 43 years (1961-2003) on crop growth and water demand in the North China Plain. Clim Change 100:559-578

China Statistics Press (2007) China rural statistics book 1949-2007. China Statistics Press, Beijing, China

Garnett ER, Khandekar ML (1992) The impact of large-scale atmospheric circulations and anomalies on Indian monsoon droughts and floods and on world grain yields-A statistical analysis. Agr Forest Meteorol 61:113-128

Gordon ND (1986) The southern oscillation and New Zealand weather. Mon weather review 114:371-387

Handler P (1990) USA corn yields, the El Niño and agricultural drought: 1867-1988. Int J Climatol 10:819-828 
Hansen JW, Hodges AW, Jones JW (1998) ENSO influences on agriculture in the Southeastern United States. J Climate 11:404-411

Huang RH, Wu YF (1989) The influence of ENSO on the summer climate change in China and its mechanism. Adv Atmos Sci 6(1):21-32

Jin MG, Zhang RQ, Gao YF (1999) Temporal and spatial soil water management: a case study in the Heiloonggang region, PR China. Agr Water Manage 42:173-187

Keating BA, Carberry PS, Hammer GL (2003) An overview of APSIM, a model designed for farming systems simulation. Eur $\mathbf{J}$ Agron 18:267-288

Lau KM, Weng HY (2001) Coherent modes of global SST and summer rainfall over China: an assessment of the regional impacts of the 1997-98 El Nino. J Clim 14:1294-1308

Lin XC, Yu SQ (1990) Climate trend in China for the last 40 years. J Meteorol 16:16-21 (in Chinese)

Lin XC, Yu SQ (1993) El Niño and rainfall during the flooding season (June-August) in China. Acta Meteorol Sinica 51:434-441 (in Chinese)

Liu YQ, Ding YH (1995) Reappraisal of the influence of ENSO events on seasonal precipitation and temperature in China. Sci Atmos Sinica 19(2):200-208

Liu Y, Wang EL, Yang XG (2010) Contributions of climatic and crop varietals changes to crop production in the North China Plain, since 1980s. Glob Chang Biol 16:2287-2299

Loon HV, Rogers JC (1981) The southern oscillation. Part II: associations with changes in the middle troposphere in the northern winter. Mon Weather Rev 109:1163-1168

Lyon DJ, Hammer GL, McLean GB, Blumenthal JM (2003) Simulation supplements field studies to determine no-till dryland corn population recommendations for semiarid western Nebraska. Agron J 95:884-891

Mavromatis T, Jagtap SS, Jones JW (2002) El Niño-Southern oscillation effects on peanut yield and nitrogen leaching. Clim Res 22:129-140

Mcbride JL, Nicholls N (1983) Seasonal relationships between Australian and Southern oscillation. Month Weather Rev 111:1998-2004

McCown RL, Hammer GL, Hargreaves JNG (1996) APSIM: a novel software system for model development, model testing and simulation in agricultural systems research. Agr Syst 50:255-271

Meinke H, Hammer GL (1995) Climatic risk to peanut production: a simulation study for northern Australia. Aust J Exp Agric 35:777-780

Meinke H, Stoner C, Hammer GL (1998) SOI phases and climatic risk to peanut production: a case study for northern Australia. Int $\mathrm{J}$ Climatol 16:783-789

Messina CD, Hansen JW, Hall AJ (1999) Land allocation conditioned on El Niño-Southern oscillation phases in the Pampas of Argentina. Agr Syst 60:197-212

Nelson RA, Dimes JP, Paningbatan EP, Silburn DM (1998) Erosion/ productivity modeling of maize farming in the Philippine uplands. Part 1. Parameterising the agricultural production systems simulator. Agric Syst 58(2):129-146

Philander SG (1990) El Niño, La Niña and the Southern Oscillation. Academic Press, San Diego, p 289
Phillips JG, Cane MA, Rosenzweig C (1998) ENSO, seasonal rainfall patterns and simulated maize yield variability in Zimbabwe. Agr Forest Meteorol 90:39-50

Ropelewski CF, Halpert MS (1986) North American precipitation and temperature patterns associated with El Niño-Southern oscillation (ENSO). Mon Weather Rev 114:2352-2362

Ropelewski CF, Halpert MS (1987) Global and regional scale precipitation patterns associated with the El Nino Southern oscillation. Mon Weather Rev 115:1606-1626

Sittel MC (1994a) Marginal probabilities of the extremes of ENSO events for temperature and precipitation in the Southeastern United States. Tech. Rep. 94-1, Center for Ocean-Atmospheric Studies, The Florida State University, Tallahassee, FL, p 155

Sittel MC (1994b) Differences in the means of ENSO extremes for maximum temperature and precipitation in the United States. Tech. Rep. 94-2, Center for Ocean-Atmospheric Studies, The Florida State University, Tallahassee, FL, p 50

Southworth J, Randolpg JC, Habeck M (2000) Consequences of future climate change and changing climate variability on maize yields in the Midwestern United States. Agric Ecosyst Environ 82:139-158

Stone RC, Hammer GL, Marcussen T (1996) Prediction of global rainfall probabilities using phases of the Southern oscillation index. Nature 384:252-255

Sun N, Feng LP (2005) Assessing the climatic risk to crop yield of winter wheat using crop growth models. Trans CSAE 21:106-110 (In Chinese)

Tao Fl, Yokozawa M, Hayashi Y, Lin E (2003) Changes in agricultural water demands and soil moisture in China over the last half-century and their effects on agricultural production. Agric For Meteorol 118:251-261

Tootle GA, Piechota TC, Singh A (2005) Coupled oceanic-atmospheric variability and U.S. streamflow. Water Resour Res 41:W12408. doi:10.1029/2005WR004381

Waddington SR (1994) Overview of the current situation and pervious impact of adaptive agricultural research on southern Africa. In: Craswell ET, Simpson J (eds) Proceedings of ACIAR/ SACCAR workshop on soil fertility and climatic constraints in dryland agriculture. Harare 1993 ACIAR, Canberra

Wang E, Robertson MR, Hammer GL (2003) Design and implementation of a generic crop module template in the cropping system model APSIM. Eur J Agron 18:121-140

Wang L, Zheng YF, Wang EL (2007) Application of agricultural production systems simulator (APSIM) in simulating the production and water use of wheat-maize continuous cropping system in North China Plain. J Appl Ecol 18:2480-2486 (In Chinese)

Yakir D, Lev-Yadun S, Zangvil A (1996) El Niño and tree growth near Jerusalem over the last 20 years. Glob Change Biol 2:97-101

Zhang RH, Akimasa S, Masahide K (1999) A diagnostic study of the impact of El Niño on the precipitation in China. Adv Atmos Sci 16:229-241

Zhang TY, Zhu J, Yang XG (2008) Correlation changes between rice yields in North and Northwest China and ENSO from 1960 to 2004. Agric For Meteorol 148:1021-1033

Zhao ZG (1989) The El Niño phenomena and temperature of China. J Meteorol 15:26-30 (in Chinese) 